\title{
Bioaccumulated trace metal profiles of Tympanotonus fuscatus, Periophthalmus barbarous and Guinearma (Sesarma) alberti collected from a perturbed freshwater mangrove swamp in Warri, Nigeria
}

\author{
$1 *$ ODIGIE, O; ${ }^{2}$ OLOMUKORO, JO \\ ${ }^{1}$ Faculty of Sciences, Benson Idahosa University, Benin City, 300001, Nigeria \\ ${ }^{2}$ Department of Animal and Environmental Biology, Faculty of Life Sciences, University of Benin, Benin City, 1154, Nigeria \\ *Corresponding Author Email: oodigie@biu.edu.ng, Tel: 08106234990
}

\begin{abstract}
Bio - concentrated levels of trace metals; $\mathrm{Fe}, \mathrm{Zn}, \mathrm{Cu}, \mathrm{Cd}$ and $\mathrm{Pb}$ in three (3) freshwater mangrove fauna; Tympanotonus fuscatus (periwinkle), Periophthalmus barbarous (mudskipper) and Guinearma (Sesarma) alberti (West African Sesarmid Crab) was investigated utilizng atomic absorbance spectrophotometery. Faunal sampling was conducted at five (5) sites in the Falcorp wetland area of Warri, Delta State, once monthly for an eighteen (18) month period. Maximal mean Fe and $\mathrm{Zn}$ values; $349.79 \mu \mathrm{g} / \mathrm{g}$, dried wt \pm 15.64 and $16.92 \mu \mathrm{g} / \mathrm{g}$, dried $\mathrm{wt} \pm 1.65$ were recorded for the respective mudskipper and crab samples while minimal mean $\mathrm{Fe}$ and $\mathrm{Zn}$ values; $124.14 \mu \mathrm{g} / \mathrm{g}$, dried wt \pm 7.85 and $7.71 \mu \mathrm{g} / \mathrm{g}$, dried wt \pm 0.96 were documented for the digested periwinkle tissues. The differences in the mean $\mathrm{Fe}, \mathrm{Zn}, \mathrm{Cu}$ and $\mathrm{Cd}$ values was siginificantly different at different levels $(P<0.001, P<0.01$ and $P<0.05$ ). The detection of significant bioconcentration of these metals especially $\mathrm{Cd}$, is a possible indication of the wide reaching deletrious ecological effects of anthropogenic activities in the affected area.
\end{abstract}

\section{DOI: https://dx.doi.org/10.4314/jasem.v25i3.20}

Copyright: Copyright $\odot 2021$ Odigie and Olomukoro. This is an open access article distributed under the Creative Commons Attribution License (CCL), which permits unrestricted use, distribution, and reproduction in any medium, provided the original work is properly cited.

Dates: Received: 12 December 2020; Revised: 26 January 2021; Accepted: 12 February 2021

Keywords: Falcorp mangrove swamp, Bioaccumulation, Trace metal, benthic bio-indicator

There has been increased research activity into heavy metal pollution in the different environmental compartments, i.e., aquatic niches, within our natural environments. This is apparently due to their toxicity and persistence especially of some trace metals grouped as non essential; e.g., $\mathrm{Pb}, \mathrm{Hg}$ and $\mathrm{Cd}$ which even at trace levels can be toxic, and have unknown functions within the existing trophic levels in these aquatic ecosystems (Mehana et al., 2020). Benthic invertebrate fauna in aquatic ecosystems play an important role in the transformation of the organic matter sediment on the bottom to its base elements and subsequently contribute to the basic nutrition of fish. The composition of the benthic fauna has largely been regarded as a good indicator of water quality because, unlike planktonic species, they form relatively stable communities in the sediments which do not change over long time periods (El- Shabrawy and Khalil, 2003). Heavy metals emnanting from either direct discharges or surface run off upon entering the aquatic environment are known to rapidly aggregrate with circulating particulate materials and eventualy settling in the aquatic bottom sediments (Abu and Nwokoma, 2016). Trace metal accumulation from the overlying water to the sediment has been known to be reliant on some extrinsic environmental factors which include; $\mathrm{pH}$, electrical conductivity and surface area availability for adsorption as a result of the difference in sediment particle size distribution ( $\mathrm{Abu}$ and Nwokoma, 2016). Sediment linked digenetic mechanisms has been known to cause changes and redistribution of these metal pollutant between the solid and the dissolved phases, but a consequence of sedimentation process is the immobilization of majority of the metallic pollutants are normally rendered immobilized through sedimentation, which therein makes these pollutant bioavailable for a host of micro and marco benthic invertebrates which include mudskippers, molluses and gastropods (Abu and Nwokoma , 2016). Heavy metal bioaccumulation in the body tissues of wildlife fauna is largely dependent on the type of heavy metal, and its concentration in the environment. The usage of benthic invertebrates as bio-indicators could help to quantify the level of bioavailabilty of these metals in different aquatic ecosystems. Benthic invertebrates take up these metal pollutants from the water, sediment litter and from food, and the pollutant concentrations in their tissues (or sometimes the changes in such concentrations) can serve as a time-integrated measurement of pollutant bioavailability (Zulkifli et al., 2012). The respective swamp faunal bio indicators utilized in this study; Tympanotonus fuscatus (periwinkle), Periophthalmus barbarous (mudskipper) and Guinearma (Sesarma) alberti (West African Sesarmid Crab) are native faunal species present in the fresh water mangrove wetlands of the Niger Delta region. The Falcorp mangrove swamp is a part of this wetland belt and the water channel within this swamp interphases with other water bodies of neighbouring creeks. The swamp has been and is currently been impacted negatively as a consequence of several human activities within its vicinity which include farming and fishing activities, dumping of petrochemical wastes, accurring from the 
activities of the nearby Warri petroleum refinery and an upsurge in bunkering (crude oil theft) and illegal refining activities within the swamp and neighbouring creeks. Several authors have reported the suitablility and effectiveness of utilizing these representative benthic fauna and mudskipper as bio indicators with respect to aquatic niches exposed to varying levels of heavy metal pollution (Ikram et al., 2010; Chaiyaraa et al., 2013; Ansari et al., 2014; Abu and Nwokoma, 2016; Moslen et al., 2017; Aigberua and Izah, 2018; Numbere, 2019; Abiaobo et al., 2020). Earlier publications by Odigie and Olomukoro (2020a; $2020 b)$ profiled the heavy metal content of surface water and sediments collected from various sampled points within the perturbed Falcorp swamp and an adjoing creek; Ifie. However, it has been observed that sole chemical evaluation of water and sediments provides insufficient data on heavy metal bioavailability in the affected environment (Chaiyaraa et al., 2013). This study attempts to evaluate the bio accumulated heavy metal profiles of respective faunal specimens; T. fuscatus (periwinkle), P. barbarous (mudskipper) and G. (Sesarma) alberti (West African Sesarmid Crab) collected from same sampled locations as previously described by Odigie and Olomukoro (2020b).

\section{MATERIALS AND METHODS}

The Study Area: As earlier described by Odigie and Olomukoro (2020a; 2020b), the Falccorp mangrove swamp is located within the jurisdiction of Warri south Local Government Area of Delta State, Southern Nigeria. The swamp area is behind the Warri refinery and petrochemical company complex. The water channel in the mangrove swamp is continually fed by precipitation during the wet season and also by water flow from surrounding creeks, rivers and surface runoffs from neighboring communities within the surrounding watershed catchment area.

Sampling Stations: The five (5) sampling locations visited in the course of this research had earlier been described by Odigie and Olomukoro (2020a; 2020b) (Fig. 1). Representative specimens of $T$. fuscatus (periwinkle), $P$. barbarous (mudskipper) and $G$. (Sesarma) alberti (West African Sesarmid Crab) were collected from the sample locations with the aid of very experienced indigent fishermen. The animal specimens were obtained at a frequency of once monthly for a period of eighteen (18) months as previously stated by Odigie and Olomukoro (2020a; 2020b).

Collection and preparation of bio-indicator specimens: At each sampling period, a total of twenty (20) periwinkles, five (5) mudskippers and five (5) crabs were collected from sampling points. The periwinkles were handpicked, while the mudskippers and crabs were collected with the aid of fishing nets and native crab traps. The handpicked periwinkles were treated, dried, marcerated and digested in accordance with procedures described by Moslen et al. (2017). The derivation of filtrate from the digested periwinkle tissue was also conducted in accordance with the method reported by Moslen et al. (2017). The collected mudskippers were prepared and treated for acid digestion with reference to procedures described by Ikram et al. (2010). Also the digested mudskipper tissue filtrate were filtered and stored in accordance with procedures reported by Ikram et al. (2010). The trapped crabs were retrived and washed with distilled water. The tissue and the carapace of the respective crabs were separated, treated and digested in accordance with methods detailed by Chaiyara et al. (2013). Pure analytical grade Nitric acid was utilized in the digestion of the marcerated crabs and mudskippers respectively

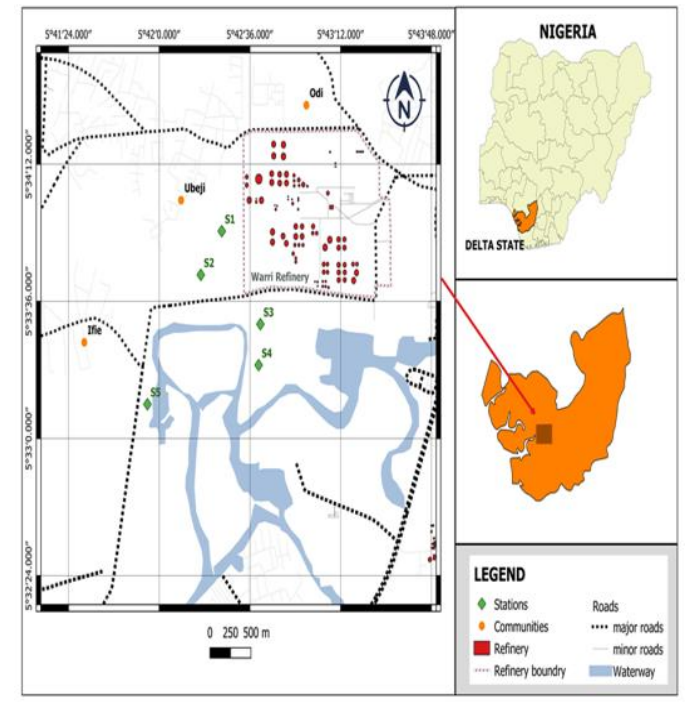

Fig. 1: Map indicating the respective sampling sites within the swamp area

Determination of selected heavy metal content of the faunal derived filtrates: The selected trace metal profiles; $\mathrm{Cu}, \mathrm{Zn}, \mathrm{Pb}, \mathrm{Cd}$ and $\mathrm{Fe}$ of the tissue filtrate derived from the periwinkles, West African Sesarmid crabs and mudskippers was evaluated using an airacetylene flame Atomic Absorption Spectrophotometer (AAS model GPC A932 ver. 1.1). Prior to usage, all glassware and plastic materials were acid washed in $10 \%$ nitric acid and later rinsed with distilled water to prevent metal contamination. Quality control samples prepared from standard solutions of $\mathrm{Fe}, \mathrm{Zn}, \mathrm{Cu}, \mathrm{Cd}$ and $\mathrm{Pb}$ were also evaluated at an interval of once for every five (5) filtrate samples to ascertain metal accuracy. Procedural blanks; digested 
distilled water without the sample were also prepared and evaluated after every five (5) samples. The obtained values were expressed as $\mu \mathrm{g} / \mathrm{g}$ wet weight. The instrumental detection limit of all the metal electrodes was $0.001 \mu \mathrm{g} / \mathrm{g}$.

Determination of the BAF and BASF values: The bioacculumation factor (BAF) and Biota Sediment Accumulation Factor (BSAF) heavy metal values for the respective bio indicators was evaluated using formula as described by Bu-Olayan and Thomas (2008) and Ziyaadini et al. (2017).

Statistical Analysis: Statistical analysis was carried out on the data generated from each sampling station using general descriptive statistics. The student $\mathrm{T}-$ test and Kruskel Wallis Test was also used to test for significance at the 0.05 level of probability for the seasons and the different stations respectively. Multivariate analysis of the available data was done using the SPSS (version 16.0) and Duncan's Multiple Range test (DMR) was utilized to locate significant difference(s) at $95 \%$ confidence interval where one existed.

\section{RESULTS AND DISCUSSION}

The summarized mean heavy metal values obtained for the bio-indicator samples is shown in Table 1 . Maximal mean Fe and $\mathrm{Zn}$ values; $349.79 \mu \mathrm{g} / \mathrm{g}$, dried wt \pm 15.64 and $16.92 \mu \mathrm{g} / \mathrm{g}$, dried wt \pm 1.65 were recorded for mudskipper and crab samples respectively (Table 1). Minimal mean $\mathrm{Fe}$ and $\mathrm{Zn}$ values; $124.14 \mu \mathrm{g} / \mathrm{g}$, dried wt \pm 7.85 and $7.71 \mu \mathrm{g} / \mathrm{g}$, dried wt \pm 0.96 were documented for digested periwinkle tissues respectively (Table 1). The highest mean $\mathrm{Cu}, \mathrm{Cd}$ and $\mathrm{Pb}$ values; $3.46 \mu \mathrm{g} / \mathrm{g}$, dried $\mathrm{wt} \pm 1.21$, $2.09 \mu \mathrm{g} / \mathrm{g}$, dried wt \pm 0.96 and $0.41 \mu \mathrm{g} / \mathrm{g}$, dried $\mathrm{wt}$ \pm 0.17 were all recorded for the sampled mudskippers while the lowest mean $\mathrm{Cu}, \mathrm{Cd}$ and $\mathrm{Pb}$ values; 0.12 $\mu \mathrm{g} / \mathrm{g}$, dried wt $\pm 0.06,0.03 \mu \mathrm{g} / \mathrm{g}$, dried wt \pm 0.01 and $0.01 \mu \mathrm{g} / \mathrm{g}$, dried wt \pm 0.01 were detected in the respective periwinkle, crab and periwinkle samples (Table 1). The observed differences in the mean $\mathrm{Pb}$ and $\mathrm{Cr}$ values across the respective biota samples was statistically insignificant $(\mathrm{P}>0.05)$ (Table 1). The differences in the mean $\mathrm{Fe}, \mathrm{Zn}, \mathrm{Cu}$ and $\mathrm{Cd}$ values was siginificantly different at different levels $(P<0.001, P<0.01$ and $P<0.05)$ (Table 1$)$.

The results for the seasonal variation for the respective bio concentrated heavy metals in $T$. fuscatus (periwinkle) is presented in Table 2. The observed differences between the seasonal mean trace metal values was statistically insignificant $(P>0.05)$ (Table $2)$. Amongst the mean bio accumulated heavy metals detected in the perwinkle tissues, Fe; $138.14 \mu \mathrm{g} / \mathrm{g}$, dried wt \pm 9.51 was the highest, while nil values were recorded in respect of $\mathrm{Cr}$ for both dry and wet seasons (Table 2). Summarized seasonal variation for the respective bio concentrated heavy metals present in $P$. barbarous (mudskipper) tissues is shown in Table 3. The differences in the mean zinc, copper, cadmium, lead and chromium readings was statistically insignificant $(P>0.05)$ (Table 3). However, the difference between the seasonal mean $\mathrm{Fe}$ values detected in the mudskipper tissues was statistically significant $(P<0.05)$ (Table 3$)$. With respect to the mean bio accumulated heavy metals detected in the mudskipper tissues, Fe; $402.48 \mu \mathrm{g} / \mathrm{g}$, dried wt \pm 20.97 was the highest, while a dry season minimal nil value was detected in respect of $\mathrm{Cr}$ (Table 3). Summarized seasonal variations for the mean bio concentrated heavy metals recorded for G. alberti (West African Sesarmid crab) tissues was presented in Table 4. The detected variations between the seasonal mean trace metal values was statistically insignificant $(P>0.05)$ (Table 4). For the mean bio accumulated heavy metals detected in the compounded West African Sesarmid crab tissues, Fe; $217.95 \mu \mathrm{g} / \mathrm{g}$, dried wt \pm 21.92 was the highest, while nil values were recorded in respect of $\mathrm{Cr}$ for both dry and wet seasons (Table 4). Significant BAF values for $\mathrm{Fe}$ and $\mathrm{Zn}$ with respect to all the examined bio -indicators were recorded (Table 5).Aside from $\mathrm{Cd}$, all the $\mathrm{BAF}$ values for the other heavy metals; $\mathrm{Fe}, \mathrm{Zn}, \mathrm{Pb}$ and $\mathrm{Cr}$ was significant in respect to the examined mudskipper tissues (Table 5). BASF values for $\mathrm{Fe}, \mathrm{Zn}$ and $\mathrm{Cu}$ were insignificant for all the bio-indicators (Table 6). Significant BASF values were recorded for cadmium with respect to all the bio indicators (Table 6). Significant BASF values for $\mathrm{Cr}$ and $\mathrm{Pb}$ with respect to West African Sesarmid crab tissues was also recorded (Table 6). In this study, there were significant differences $(p<0.05,0.01$, $0.001)$ in the bio concentrated heavy metal levels in all studied biota (Periwinkle, Crab, Mudskipper) with the exception of $\mathrm{Pb}$ and $\mathrm{Cr}$ (Table 1). Higher concentrations of heavy metals were obtained in the dry season than the wet season with $P$. barbarous (mudskipper) having more comparative bio accumulated levels of $\mathrm{Fe}, \mathrm{Cd}, \mathrm{Cu}$ and $\mathrm{Cr}$ respectively (Table 3). The detection of varying levels of $\mathrm{Zn}, \mathrm{Pb}$, $\mathrm{Fe}, \mathrm{Cu}$ and $\mathrm{Cd}$ in all the examined benthic bioindcators collaborated previously documented findings by Odigie and Olomukoro (2020b) which indicated the presence of these trace metals in sediments obtained from the same sampled sites. However, aside from mudskipper specimens collected in the wet season, all the periwinkle and crab specimens did not bioaccumulate $\mathrm{Cr}$ (Table 1-4), despite the presence of this metal in the surrounding sediments as earlier reported by Odigie and Olomukoro (2020b).. 
Table 1: Summarized mean heavy metal profiles of the different bio-indicator specimens collected from Falcorp Mangrove

\begin{tabular}{|c|c|c|c|c|c|}
\hline \multirow[t]{2}{*}{ Parameter } & Periwinkle & Mudskipper & $\begin{array}{l}\text { West African } \\
\text { Sesarmid crab }\end{array}$ & \multirow[t]{2}{*}{$\begin{array}{l}\text { P- } \\
\text { value }\end{array}$} & \multirow[t]{2}{*}{$\begin{array}{l}\text { Significant- } \\
\text { Level }\end{array}$} \\
\hline & $\overline{\mathrm{X}}_{ \pm \text {S.E }}$ & $\overline{\mathrm{X}}_{ \pm \text {S.E }}$ & $\overline{\mathrm{X}}_{ \pm \text {S.E }}$ & & \\
\hline $\begin{array}{l}\text { Iron }(\mu \mathrm{g} / \mathrm{g}, \text { dried wt) } \\
\text { (Min-Max) }\end{array}$ & $\begin{array}{l}124.14 \pm 7.85^{5} \\
(72.12- \\
175.23)\end{array}$ & $\begin{array}{l}349.79 \pm 15.64^{2} \\
(201.02- \\
498.77)\end{array}$ & $\begin{array}{l}187.78 \pm 13.31^{b} \\
(106.33- \\
281.08)\end{array}$ & 0.00 & $P<0.001^{4+4}$ \\
\hline $\begin{array}{l}\text { Zinc }(\mu \mathrm{g} / \mathrm{g}, \text { dried wt) } \\
\text { (Min-Max) }\end{array}$ & $\begin{array}{l}7.71=0.96^{\circ} \\
(1.99-13.07)\end{array}$ & $\begin{array}{l}12.69 \pm 1.20^{\mathrm{b}} \\
(2.44-19.39)\end{array}$ & $\begin{array}{l}16.92 \pm 1.65^{2} \\
(3.94-27.03)\end{array}$ & 0.00 & $P<0.001^{*+4}$ \\
\hline $\begin{array}{l}\text { Copper (ug/g, dried wt) } \\
\text { (Min-Max) }\end{array}$ & $\begin{array}{l}0.12=0.06^{6} \\
(0.01-1.07)\end{array}$ & $\begin{array}{l}3.46 \pm 1.21^{2} \\
(0.03-16.14)\end{array}$ & $\begin{array}{l}0.26 \pm 0.07^{\mathrm{b}} \\
(0.01-0.92)\end{array}$ & 0.00 & $P<0.01^{* *}$ \\
\hline $\begin{array}{l}\text { Cadmium }(\mu \mathrm{g} / \mathrm{g} \text {, dried wt) } \\
(\mathrm{Min}-\mathrm{Max})\end{array}$ & $\begin{array}{l}0.49=0.48^{6} \\
(0.001-8.70)\end{array}$ & $\begin{array}{l}2.09=0.96^{2} \\
(0.00-10.81)\end{array}$ & $\begin{array}{l}0.03=0.01^{e} \\
(0.00-0.07)\end{array}$ & 0.06 & $P<0.05^{*}$ \\
\hline $\begin{array}{l}\text { Lead }(\mu g / g, \text { dried wt) } \\
\text { (Min-Max) }\end{array}$ & $\begin{array}{l}0.01=0.01 \\
(0.00-0.09)\end{array}$ & $\begin{array}{l}0.41=0.17 \\
(0.00-2.09)\end{array}$ & $\begin{array}{l}0.37=0.25 \\
(0.00-3.56)\end{array}$ & 0.21 & $P>0.05$ \\
\hline $\begin{array}{l}\text { Chromium ( } \mu \mathrm{g} / \mathrm{g}, \text { dried wt) } \\
\text { (Min-Max) }\end{array}$ & $\begin{array}{l}0.00=0.00 \\
(0.00-0.00)\end{array}$ & $\begin{array}{l}0.19=0.18 \\
(0.00-3.18)\end{array}$ & $\begin{array}{l}0.00=0.000 \\
(0.00-0.00)\end{array}$ & 0.33 & $P>0.05$ \\
\hline
\end{tabular}

Note: $P<0.001$-There is very highly significant difference, $P<0.01$-There is highly significant difference $* *, P<0.05-$ There is significant

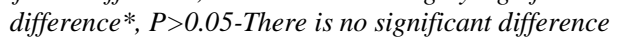

Table 2: Summarized seasonal mean bio accumulated trace metal values for T. Fuscatus (periwinkle) samples collected from Falcorp

\begin{tabular}{|c|c|c|c|c|}
\hline \multirow[t]{2}{*}{ Parameter } & Dry season & Wet season & \multirow{2}{*}{$\begin{array}{l}\text { P- } \\
\text { value }\end{array}$} & \multirow{2}{*}{$\begin{array}{l}\text { Significance } \\
\text { level }\end{array}$} \\
\hline & $\overline{\overline{\mathbf{X}}_{ \pm} \mathrm{S} . \mathrm{E}}$ & $\overline{\overline{\mathbf{X}}_{ \pm} \text {S.E }}$ & & \\
\hline $\mathrm{Fe}(\mu \mathrm{g} / \mathrm{g}$, dried wt $)$ & $138.14 \pm 9.51$ & $115.23 \pm 10.80$ & 0.16 & $P>0.05$ \\
\hline $\mathrm{Zn}(\mu \mathrm{g} / \mathrm{g}$, dried $w \mathrm{t})$ & $7.35 \pm 1.92$ & $7.93 \pm 1.07$ & 0.78 & $P>0.05$ \\
\hline $\mathrm{Cu}(\mu \mathrm{g} / \mathrm{g}$, dried $\mathrm{wt})$ & $0.04 \pm 0.02$ & $0.17 \pm 0.09$ & 0.28 & $P>0.05$ \\
\hline $\mathrm{Cd}(\mu \mathrm{g} / \mathrm{g}$, dried wt $)$ & $0.02 \pm 0.00$ & $0.81 \pm 0.79$ & 0.44 & $P>0.05$ \\
\hline $\mathrm{Pb}(\mu \mathrm{g} / \mathrm{g}$, dried $w \mathrm{t})$ & $0.00 \pm 0.00$ & $0.01 \pm 0.01$ & 0.36 & $P>0.05$ \\
\hline $\mathrm{Cr}(\mu \mathrm{g} / \mathrm{g}$, dried $w \mathrm{t})$ & $0.00 \pm 0.00$ & $0.00 \pm 0.00$ & 0.29 & $P>0.05$ \\
\hline
\end{tabular}

Note: $P>0.05$-There is no significant difference amongst the mean values

Table 3: Summarized seasonal mean bio accumulated trace metal values for P. barbarous (mudskipper) samples collected from Falcorp Mangrove swamp

\begin{tabular}{|c|c|c|c|c|}
\hline Parameter & Dry season & Wet season & P- & Significance \\
\hline & & & & \\
\hline $\mathrm{Fe}(\mu \mathrm{g} / \mathrm{g}$, dried $\mathrm{wt})$ & $402.48 \pm 20.97$ & $316.26 \pm 14.95$ & 0.00 & $P<0.01 *$ \\
\hline $\mathrm{Zn}(\mu \mathrm{g} / \mathrm{g}$, dried wt) & $11.94 \pm 1.92$ & $13.18 \pm 1.59$ & 0.63 & $P>0.05$ \\
\hline $\mathrm{Cu}(\mu \mathrm{g} / \mathrm{g}$, dried $w \mathrm{t})$ & $2.98 \pm 0.99$ & $3.77 \pm 1.92$ & 0.76 & $P>0.05$ \\
\hline $\mathrm{Cd}(\mu \mathrm{g} / \mathrm{g}$, dried $w \mathrm{t})$ & $0.72 \pm 0.28$ & $2.96 \pm 1.52$ & 0.26 & $P>0.05$ \\
\hline $\mathrm{Pb}(\mu \mathrm{g} / \mathrm{g}$, dried $\mathrm{wt})$ & $0.61 \pm 0.38$ & $0.29 \pm 0.15$ & 0.38 & $P>0.05$ \\
\hline $\mathrm{Cr}(\mu \mathrm{g} / \mathrm{g}$, dried $w \mathrm{t})$ & $0.00 \pm 0.00$ & $0.31 \pm 0.29$ & 0.41 & $P>0.05$ \\
\hline
\end{tabular}

Note: $P<0.01$-There is highly significant difference*, $P>0.05$-There is no significant difference

Table 4: Summarized seasonal mean bio accumulated trace metal values for G. alberti (West African Sesarmid crab) samples collected from Falcorp Mangrove swamp

\begin{tabular}{|c|c|c|c|c|}
\hline \multirow[t]{2}{*}{ Parameter } & Dry season & Wet season & \multirow{2}{*}{$\begin{array}{l}P \text { - } \\
\text { value }\end{array}$} & \multirow{2}{*}{$\begin{array}{l}\text { Significance } \\
\text { level }\end{array}$} \\
\hline & $\overline{\mathbf{X}}_{ \pm \text {S.E }}$ & $\overline{\mathbf{X}}_{ \pm \text {S.E }}$ & & \\
\hline $\mathrm{Fe}(\mu \mathrm{g} / \mathrm{g}$, dried $w \mathrm{t})$ & $217.95 \pm 21.92$ & $168.58 \pm 14.64$ & 0.07 & $P>0.05$ \\
\hline $\mathrm{Zn}(\mu \mathrm{g} / \mathrm{g}$, dried wt) & $15.20 \pm 1.94$ & $18.01 \pm 2.42$ & 0.42 & $P>0.05$ \\
\hline $\mathrm{Cu}(\mu \mathrm{g} / \mathrm{g}$, dried wt $)$ & $0.24 \pm 0.12$ & $0.27 \pm 0.09$ & 0.85 & $P>0.05$ \\
\hline $\mathrm{Cd}(\mu \mathrm{g} / \mathrm{g}$, dried $w \mathrm{t})$ & $0.03 \pm 0.01$ & $0.02 \pm 0.01$ & 0.39 & $P>0.05$ \\
\hline $\mathrm{Pb}(\mu \mathrm{g} / \mathrm{g}$, dried $\mathrm{wt})$ & $0.00 \pm 0.00$ & $0.61 \pm 0.40$ & 0.25 & $P>0.05$ \\
\hline $\mathrm{Cr}(\mu \mathrm{g} / \mathrm{g}$, dried wt $)$ & $0.00 \pm 0.00$ & $0.00 \pm 0.00$ & 0.58 & $P>0.05$ \\
\hline
\end{tabular}

Note: $P>0.05$-There is no significant difference

Table 5: BAF values for the bio-concentrated heavy metals

\begin{tabular}{llll}
\hline Heavy metal & Mudskipper & West African Sesarmid crab & Periwinkle \\
\hline $\mathrm{Fe}(\mu \mathrm{g} / \mathrm{g}$, dried $w \mathrm{t})$ & $\mathbf{3 . 4 4}$ & $\mathbf{1 . 2 2}$ & $\mathbf{2 . 1 3}$ \\
$\mathrm{Zn}(\mu \mathrm{g} / \mathrm{g}$, dried $w \mathrm{t})$ & $\mathbf{3 . 5 9}$ & $\mathbf{1 . 8 5}$ & $\mathbf{1 . 3 6}$ \\
$\mathrm{Cu}(\mu \mathrm{g} / \mathrm{g}$, dried $w \mathrm{t})$ & $\mathbf{1 0 . 4 5}$ & 0.18 & $\mathbf{2 . 1 1}$ \\
$\mathrm{Cd}(\mu \mathrm{g} / \mathrm{g}$, dried $\mathrm{wt})$ & 0.02 & 0.01 & 0.25 \\
$\mathrm{~Pb}(\mu \mathrm{g} / \mathrm{g}$, dried $w \mathrm{t})$ & $\mathbf{6 . 2 1}$ & 0.15 & 0.05 \\
$\mathrm{Cr}(\mu \mathrm{g} / \mathrm{g}$, dried $\mathrm{wt})$ & $\mathbf{1 2 . 0 4}$ & 0.05 & 11.92 \\
\hline
\end{tabular}

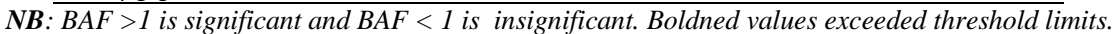

Table 6: BSAF values for the bio-concentrated heavy metals

\begin{tabular}{llll}
\hline BSAF & Mudskipper & West African Sesarmid crab & Periwinkle \\
\hline $\mathrm{Fe}(\mu \mathrm{g} / \mathrm{g}$, dried wt) & 0.29 & 0.82 & 0.47 \\
$\mathrm{Zn}(\mu \mathrm{g} / \mathrm{g}$, dried wt) & 0.28 & 0.54 & 0.73 \\
$\mathrm{Cu}(\mu \mathrm{g} / \mathrm{g}$, dried $w \mathrm{t})$ & 0.10 & 5.65 & 0.47 \\
$\mathrm{Cd}(\mu \mathrm{g} / \mathrm{g}$, dried $\mathrm{wt})$ & $\mathbf{4 3 . 7 5}$ & $\mathbf{2 2 2 . 4 1}$ & $\mathbf{4 . 0 5}$ \\
$\mathrm{Pb}(\mu \mathrm{g} / \mathrm{g}$, dried $\mathrm{wt})$ & 0.16 & $\mathbf{6 . 9 1}$ & $\mathbf{2 0 . 7 6}$ \\
$\mathrm{Cr}(\mu \mathrm{g} / \mathrm{g}$, dried $w \mathrm{t})$ & 0.08 & $\mathbf{2 0 . 5 5}$ & 0.08
\end{tabular}

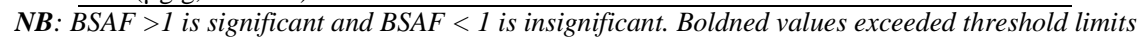

ODIGIE, O; OLOMUKORO, JO 
This trend would indicate the non suitability of utilizing T. fuscatus (periwinkle) and G. (Sesarma) alberti (West African Sesarmid crabs) as potential bioindicators of $\mathrm{Cr}$ contamination of estuarine niches. Periwinkles and mudskippers are a common part of the daily diet of some human communities residing in the Niger-Delta region of Nigeria.

Goyer, (1991) reported that cadmium can bioaccumulate in mussels, oysters, prawns, lobsters and fish and documented that several related health risks such as high blood-pressure, liver disease and nerve or brain damage can occur if these heavy metal tainted foods are consumed beyond threshold limits. Several studies have also reported the bioconcentration of heavy metals in several types of aquatic biota. Ayenimo et al., (2005) reported appreciable quantities of heavy metals such as iron, copper, barium, lead, cadmium and nickel in periwinkles purchased from public markets in Warri River, Nigeria. Also, Falusi and Olanipekun (2007), also documented high bioconcentration of heavy metals in tropical crab (Carcinus sp.) harvested from River Aponwe, Ado-Ekiti. Olalode et al. (2008) reported high concentrations of manganese and zinc in crabs, while elevated levels of cobalt, copper and iron were detected in periwinkles. Ikejimba and Sakpa (2014) reported higher bioaccumulation of some heavy metals in periwinkles collected from Egboko River.

Aside from the associated BAF value for $\mathrm{Cd}$, the BAF values for all the trace metals with respect to the collected mudskipper specimens were higher than threshold value of 1 (Table 5). This trend might be reflective of their feeding habit as Periophthalmus species are carnivorous mudskippers known to prey on little crabs and other arthropods (Ansari et al., 2014). The BAF values recorded for the examined mudskippers also indicated the strong possibility of bioaccumulation of trace metals in several internal tissues of the mudskippers such as the gills, muscles and the digestive system respectively (Ansari et al., 2014). Long term exposure to cadmium is known to primarily affect the kidneys, resulting in tubular proteinosis (Goyer, 1991). As Cd and Zn are known to possess identical oxidation states, $\mathrm{Cd}$ can replace $\mathrm{Zn}$ present in metallothionein, thereby inhibiting $\mathrm{Zn}$ from performing its role as a cellular scavenger of free radicals (Jaishankar et al., 2014). Worryingly, high BASF levels of $\mathrm{Cd}$ were deduced with respect to all the faunal specimens and $\mathrm{Pb}$ levels were significantly higher for crab and periwinkle samples respectively (Table 6). This trend would indicate the non suitablility of the aquatic fauna as food source for indigent human communities which are known to depend on these mangrove fauna as source of protein. This trend also buttress the urgent need for further investigations into the bio-concentrated levels of heavy metals in other aquatic fauna such as fishes, prawns, molluscs and crayfish popularly consumed by residents within the study area and other parts of the freshwater ecosystems within Delta State, Southern Nigeria. Lead has been documented to have deleterious effe cts on human health (Jaishankar et al., 2014). Pb has also been regarded as a carcinogenic metal and its toxicity can be either acute or chronic (Jaishankar et al., 2014). Acute $\mathrm{Pb}$ toxicity has been known to cause symptoms which vary from appetite loss, headache, hypertension, abdominal pain, renal dysfunction, fatigue, and sleeplessness to arthritis respectively (Jaishankar et al., 2014). . Chronic exposure to $\mathrm{Pb}$ can culminate in symptoms which range from mental retardation, birth defects, psychosis, autism, allergies, dyslexia, weight loss, brain damage, kidney damage and in some situations mortality (Jaishankar et al., 2014). Chaiyaraa et al. (2013) outlined the importance of investigating trace metal concentrations in marine organisms as these studies can reveal the likely public health risks, these aquatic organisms may constitute for unsuspecting consumers.

Conclusion: Significant BAF and BSAF values with respect to $\mathrm{Zn}$ and $\mathrm{Cd}$ were recorded for the examined benthic faunal indicators. Although, currently there is a dearth of appropriate Nigerian standards on permissible trace metal levels in marine and aquatic fauna meant for human consumption, the detection of significant bioacumulated levels of these metals especially $\mathrm{Cd}$, might be indicative of the wide reaching deletrious ecological effects of anthropogenic activities in the affected area.

\section{REFERENCES}

Abiaobo, NO; Asuquo, EI; Akpabio, PE (2020). Heavy metal bioaccumulation in Periwinkle (Tympanotonus fuscatus) and Tilapia fish (Oreochromis niloticus) samples harvested from a perturbed tropical creek in the Niger Delta, Nigeria. Asian J. Environ. Ecol. 12 (1): 18-27

Abu, OMG; Nwokoma, GC (2016). Bioaccumulation of selected heavy metals in water, sediment and Blue Crab (Callinectes amnicola) from Bodo Creek, Niger Delta, Nigeria. J. Fish. Sci. 10 (3): 77-83.

Aigberua, OA; Izah, CS (2018). Evaluation of heavy metals in tissue of Tympanotonus fuscatus sold in some markets in Port Harcourt metropolis, Nigeria. MOJ Toxicol. 4(5):334-338.

Ansari, AA; Trivedi, S; Saggu, S; Rehman, H (2014). Mudskipper: A biological indicator for environmental monitoring and assessment of coastal waters. J. Entomol. Zool. Stud. 2 (6): 22-33

Ayenimo, JG; Adeeyinwo, CE; Amoo, IA; Odukudu, FB (2005). A preliminary investigation of heavy 
metals in periwinkles from Warri River. J. Appl. Sci. 5 (5):813-815.

Bu-Olayan, AH; Thomas, BV (2008). Trace metals toxicity and bioaccumulation in Mudskipper Periophthalmus waltoni Koumans 1941 (Gobiidae: Perciformes). Turk. J. Fish. Aqua. Sci. 8: 215218.

Chaiyaraa, R; Ngoendeeb, M; Kruatrachue, M (2013). Accumulation of $\mathrm{Cd}, \mathrm{Cu}, \mathrm{Pb}$, and $\mathrm{Zn}$ in water, sediments, and mangrove crabs (Sesarma mederi) in the upper Gulf of Thailand. Sci. Asia, 39: 376383.

El-Shabrawy, GM; Khalil, MT (2003). Macrobenthos of Lake Bardawil and Zaranik Lagoon. A report presented to Nature Conservation Sector, EEAA. Med Wet Coast Project, Conservation of Wetland and Coastal Ecosystems in the Mediterranean Region, Ecological Survey of Zaranik Nature Protectorate, GEF, Pp 30.

Falusi, BA; Olanipekun, EO (2007). Bioconcentration factors of heavy metals in tropical crab (Carcinus sp.) from River Aponwe, Ado-Ekiti, Nigeria. J. Appl. Sci. Environ. Manage. 11(4) 51 - 54.

Goyer, R (1991). Toxic Effects of Metals. In: Amdur, MO; Doull, JD; Klassen, CD (eds) Casarett and Doull's Toxicology, 4th edn. Pergamon Press, New York, p. 623-680.

Ikejimba, CC; Sakpa, S (2014). Comparative study of some heavy metals' concentrations in water and Tympanotonus fuscatus var radula samples of Egbokodo River, Warri, Nigeria. Inter. J. Modern Biol. Res. 2 (1):7-15.

Ikram, MM; Ismail, A; Yapb, CK; Azwady, NAA (2010). Levels of heavy metals ( $\mathrm{Zn}, \mathrm{Cu}, \mathrm{Cd}$, and $\mathrm{Pb}$ ) in mudskippers (Periophthalmodon schlosseri) and sediments collected from intertidal areas at Morib and Remis, Peninsular Malaysia. Toxicol. Environ. Chem. 92 (8):1471-1486.

Jaishankar, M; Tseten, T; Anbalagan, N; Mathew, BB; Beeregowda, KN (2014). Toxicity, mechanism and health effects of some heavy metals. Interdiscip. Toxicol. 7(2): 60-72.
Mehana, EE; Khafaga, AF; Elblehi, SS; El-Hack , AEM; Naiel, AEM; Bin-Jumah, M; Othman, IS; Allam, AA (2020). Biomonitoring of heavy metal pollution using Acanthocephalans parasite in ecosystem: An updated overview. Animals 10: 811-826.

Moslen, M; Ekweozor, KEI; Nwoka, ND (2017). Assessment of heavy metals and bioaccumulation in Periwinkle (Tympanotonus fuscatus var. radula (L) Obtained from the upper reaches of the Bonny estuary, Nigeria. J. Heavy Metal Tox. Dis. 2 (2):38.

Odigie, O; Olomukoro, JO (2020a). Physicochemical profiles and water quality indices of surface waters collected from Falcorp mangrove swamp, Delta State, Nigeria. J. Appl. Sci. Environ. Manage. 24 (2) 357-365.

Odigie, O; Olomukoro, JO (2020b). Selected physicochemical evaluation of sediments from a mangrove swamp in Warri, Southern Nigeria. NIPES J. Sci. Technol. Res. 2(4): $62-73$.

Numbere, AO (2019). Bioaccumulation of total hydrocarbon and heavy metals in body parts of the West African Red Mangrove Crab (Goniopsis pelii) in the Niger Delta, Nigeria. Inter. Letters. Nat. Sci. 75:1-12.

Ololade, IA; Lajide, L; Amoo, IA; Oladoja, NA (2008). Investigation of heavy metals contamination of edible marine seafood. Afr. J. Pure. Appl. Chem. 2 (12):121-131.

Ziyaadini, M; Yousefiyanpour, Z; Ghasemzadeh, J; Zahedi, MM (2017). Biota-sediment accumulation factor and concentration of heavy metals $(\mathrm{Hg}, \mathrm{Cd}$, $\mathrm{As}, \mathrm{Ni}, \mathrm{Pb}$ and $\mathrm{Cu}$ ) in sediments and tissues of Chiton lamyi (Mollusca: Polyplacophora: Chitonidae) in Chabahar Bay, Iran. Iranian J. Fish. Sci. 16 (4) 1123-1134.

Zulkifli, SZ; Ismail, A; Mohamat, YF (2012). Bioaccumulation of Selected Heavy Metals in Soldier Crabs, Dotillamyctiroides (Decapoda: Ocypodidae) from Bagan Lalang, Selangor, Malaysia. Acta Biol. Malay. 21: 94-100 